\title{
Pengaruh Model Pembelajaran Inside Outside Circle (IOC) Terhadap Hasil Belajar IPA
}

\author{
Ni M.S. Utami ${ }^{*}$, Ni N. Kusmariyatni², N.T. Renda ${ }^{3}$ \\ 1,2,3 Jurusan Pendidikan Guru Sekolah Dasar (PGSD), Universitas Pendidikan Ganesha, Singaraja, Indonesia.
}

\author{
A R T I C L E I N F O \\ Article history: \\ Received 20 May 2018 \\ Received in revised form \\ 6 June 2018 \\ Accepted 10 July 2018 \\ Available online 20 August \\ 2018 \\ Kata Kunci: \\ Hasil Belajar IPA, Inside \\ Outside Circle \\ Keywords: \\ Inside Outside Circle, result \\ of science
}

\begin{abstract}
A B S T R A K
Penelitian ini bertujuan untuk mengetahui perbedaan yang signifikan hasil belajar IPA antara siswa yang mengikuti pembelajaran dengan menggunakan model pembelajaran Inside Outside Circle dengan siswa yang mengikuti pembelajaran konvensional pada siswa kelas V di SD Gugus III Kecamatan Jembrana Kabupaten Jembrana Tahun Pelajaran 2017/2018. Jenis penelitian ini adalah penelitian eksperimen semu. Populasi penelitian ini adalah seluruh siswa kelas $\mathrm{V}$ di SD Gugus III Kecamatan Jembrana Kabupaten Jembrana Tahun Pelajaran 2017/2018 dengan jumlah 149 siswa. Sampel penelitian ini adalah siswa kelas V SD Negeri 2 Dauhwaru yang berjumlah 20 siswa dan siswa kelas V SD Negeri 4 Dauhwaru yang berjumlah 25 siswa. Data hasil belajar IPA siswa dikumpulkan dengan tes berbentuk pilihan ganda. Data yang dikumpulkan dianalisis dengan menggunakan analisis statistik deskriptif dan statistik inferensial (uji-t). Dilihat dari hasil uji-t diperoleh thitung $=3,06$ dan ttabel $(\mathrm{db}=43$ pada taraf signifikansi $5 \%$ ) $=2,021$. Hal ini berarti bahwa thitung > ttabel, sedangkan hasil perhitungan rata-rata hasil belajar IPA yang dibelajarkan menggunakan model pembelajaran Inside Outside Circle adalah 19,35 lebih besar dibandingkan dengan yang dibelajarkan dengan pembelajaran konvensional adalah 15,32. Dengan demikian, model pembelajaran Inside Outside Circle berpengaruh terhadap hasil belajar IPA siswa kelas V di SD Gugus III Kecamatan Jembrana Kabupaten Jembrana Tahun Pelajaran 2017/2018
\end{abstract}

\section{A B S T RAC T}

This study was aimed to determine the differences between of the science learning outcomes of students who take the learning to Inside Outside Circle model with students who take the conventional learning of the fifth grade of SD Cluster III, Jembrana Subdistrict, Jembrana Regency in the academic year 2017/2018. The study was quasi-experimental. The population of this study was the all of the students that was 149 students in the fifth grade of of SD Cluster III, Jembrana Subdistrict, Jembrana Regency in the academic year 2017/2018. The Samples of this research are students of class V SDN 2 Dauhwaru, which amounted to 20 students and students of class V SDN 4 Dauhwaru, which amounted to 25 students. Science student learning outcomes data collected by multiple choice tests. Data collected were analyzed using descriptive statistics analysis and inferential statistics (t-test). Judging from the t-test results obtained $t$ count $=3,06$ and t table $(\mathrm{db}=50$ at a significance level of $5 \%)=2,021$. It is means that tcount $>t$ table, while the result of the average calculation science learning outcomes that learning to Inside Outside Circle model is 19,35 greater than that learned with the conventional learning is 15,32. It means that inside Outside Cicrle model has an effect of students' achievement in science lesson in the 5th Grade of SD Cluster III, Jembrana Subdistrict, Jembrana Regency in the academic year 2017/2018.. 


\section{Pendahuluan}

Pendidikan memiliki peran penting dalam memajukan bangsa untuk mencapai tujuan Negara Indonesia. Pendidikan merupakan proses dasar dari perkembangan hidup manusia. Karena dengan belajar, manusia melakukan perubahan kualitas hidup sehingga tingkah lakunya berkembang (Azmi, 2015). Pendidikan hendaknya mampu mengembangkan potensi kecerdasan serta bakat yang dimiliki peserta didik secara optimal sehingga peserta didik dapat mengembangkan potensi diri yang dimilikinya menjadi suatu prestasi yang punya nilai jual (Ningsih, 2017). Melalui pendidikan akan mampu meningkatkan kualitas sumber daya manusia. Upaya untuk membentuk sumber daya manusia yang berkualitas di dukung oleh tujuan pendidikan nasional. Untuk mencapai tujuan pendidikan salah satunya dapat ditempuh melalui pendidikan formal yang memberikan peluang bagi peserta didik untuk mengembangkan potensinya. Pendidikan sangat erat kaitannya dengan pembelajaran, dalam pendidikan formal proses pembelajaran dilaksanakan di sekolah.

Pada kurikulum 2013, proses pembelajaran yang diterapkan pada jenjang sekolah dasar adalah pembelajaran tematik,. IPA merupakan salah satu muatan pelajaran yang sering muncul dalam kegiatan pembelajaran karena berhubungan langsung dengan lingkungan siswa. UU No. 20 tahun 2003 Pasal 37 menyatakan bahwa "bahan kajian Ilmu Pengetahuan Alam dimaksudkan untuk mengembangkan pengetahuan, pemahaman, dan kemampuan analisis peserta didik terhadap lingkungan alam sekitar". Lingkungan sebagai sumber belajar merupakan suatu proses pembelajaran yang meningkatkan keterlibatan peserta didik melalui pembelajaran berbasis lingkungan sebagai sumber belajar (Susanti, 2017).

Pembelajaran IPA di sekolah dasar menekankan pada pemberian pengalaman langsung untuk mengembangkan kompetensi agar dapat menjelajahi dan memahami alam sekitar secara ilmiah. Sejalan dengan hal tersebut menurut Sudana, dkk (2016:11) dikatakan "setiap pembelajaran, termasuk pembelajaran IPA hendaknya dapat menciptakan situasi pembelajaran yang Interaktif, Inspiratif, Menantang, Memotivasi dan Menyenangkan". Melalui pembelajaran IPA, diharapkan siswa dapat meningkatkan kemampuan menyesuaikan diri dengan perubahan dan memasuki dunia teknologi, termasuk teknologi informasi. Dalam pelaksanaan pembelajaran IPA peran guru sangatlah penting untuk menciptakan kondisi belajar yang memungkinkan siswa berprestasi secara optimal. Dalam pelaksanaan kegiatan pembelajaran guru hendaknya memilih dan menggunakan strategi yang melibatkan siswa secara aktif dalam belajar, baik dari segi pengetahuan, sikap dan keterampilan sehingga tujuan pembelajaran dapat tercapai.

Namun kenyataannya pencapaian hasil belajar IPA di sekolah dasar belum mencapai hasil belajar yang diharapkan. Pada tanggal 30 November 2017 dan 4 Desesmber 2017 dilakukan wawancara, observasi dan studi dokumen kepada beberapa guru khususnya guru wali kelas V SD di Gugus III Kecamatan Jembrana Kabupaten Jembrana.

Berdasarkan hasil wawancara tentang masalah yang dialami dalam melaksanakan pembelajaran IPA yaitu: 1) Kurangnya keaktifan siswa dalam mengikuti proses pembelajaran; 2) Tingkat daya serap siswa terhadap materi pelajaran masih rendah sehingga guru harus melakukan beberapa kali pengulangan dalam penyampaian materi; 3) Siswa kurang bersemangat dalam mengikuti pembelajaran.

Untuk memperkuat hasil wawancara dilakukan observasi pada saat pelaksanaan pembelajaran di kelas dan nampak bahwa beberapa masalah dalam pembelajaran IPA yaitu: 1) Pola pembelajaran masih berpusat pada guru (teacher centered) sehingga siswa cenderung pasif karena hanya mendengarkan penjelasan dari guru; 2) Konsentrasi siswa ketika mengikuti pembelajaran tidak bertahan lama tetapi cenderung sibuk sendiri, bercanda atau mengobrol dengan teman sebangku; 3) Guru kurang melibatkan siswa dalam proses pembelajaran sehingga pembelajaran dirasakan membosankan oleh siswa.

Permasalahan pembelajaran yang telah dipaparkan di atas, mengakibatkan proses pembelajaran berlangsung kurang maksimal. Jika situasi pembelajaran dilaksanakan seperti kondisi tersebut, maka akan mengakibatkan rendahnya hasil belajar siswa yang pada akhirnya tujuan pembelajaran tidak akan tercapai. Berdasarkan studi dokumen yang telah dilakukan di Gugus III Kecamatan Jembrana diperoleh data hasil Ulangan Akhir Semester I muatan pelajaran IPA kelas V yang disajikan pada Tabel 1 berikut. 
Tabel 1. Rata-rata Nilai Ulangan Akhir Semester (UAS) Semester I Muatan Pelajaran IPA

\begin{tabular}{cccccccc}
\hline Nama & Kelas & $\begin{array}{c}\text { Jumlah } \\
\text { Siswa }\end{array}$ & KKM & $\begin{array}{c}\text { Rata- } \\
\text { rata }\end{array}$ & $\begin{array}{c}\text { Ketuntasan } \\
\text { Sudah }\end{array}$ & Belum & $\begin{array}{c}\text { Presentase } \\
\text { tuntas }\end{array}$ \\
\hline SD 1 Dauhwaru & $\mathrm{V}$ & 13 & 68 & 66,38 & 5 & 8 & $38,46 \%$ \\
SD 2 Dauhwaru & $\mathrm{V}$ & 20 & 70 & 67,15 & 7 & 13 & $35 \%$ \\
SD 3 Dauhwaru & $\mathrm{VA}$ & 25 & 71 & 68,76 & 6 & 19 & $24 \%$ \\
SD 3 Dauhwaru & $\mathrm{VB}$ & 25 & 71 & 68,84 & 7 & 18 & $28 \%$ \\
SD 4 Dauhwaru & $\mathrm{V}$ & 25 & 68 & 66,76 & 11 & 14 & $44 \%$ \\
SD 5 Dauhwaru & $\mathrm{V}$ & 16 & 71 & 71,19 & 7 & 9 & $43,57 \%$ \\
SD 6 Dauhwaru & $\mathrm{V}$ & 25 & 70 & 68,84 & 12 & 13 & $48 \%$ \\
Jumlah & & 149 & & & 55 & 94 & \\
\hline
\end{tabular}

Berdasarkan tabel nilai rata-rata UAS semester I muatan pelajaran IPA siswa kelas V di Gugus III Kecamatan Jembrana, dapat dilihat nilai rata-rata kelas pada masing-masing sekolah berkisar antara 66,38 sampai 71,19, jika dikonversikan menurut Agung (2016:146) berdasarkan klasifikasi pada Skala Lima berada pada kecenderungan katagori sedang, sehingga masih perlu ditingkatkan.

Berdasarkan permasalahan tersebut, diperlukan suatu solusi pembelajaran yang dapat menciptakan pembelajaran yang interaktif, memfasilitasi siswa dalam belajar, dan melibatkan peran aktif siswa saat mengikuti pelajaran dan dapat mengubah proses pembelajaran yang awalnya berpusat pada guru menjadi belajar yang berpusat pada siswa dengan menempatkan siswa sebagai subyek belajar. Guru harus mampu menggunakan model pembelajaran dengan tepat untuk meningkatkan hasil belajar IPA siswa. Salah satu model yang efektif untuk mengatasi masalah-masalah tersebut adalah dengan menerapkan model pembelajaran Inside Outside Circle karena memungkinkan setiap siswa untuk terlibat aktif dan disiplin dalam pembelajaran dengan suasana yang menyenangkan. Keaktifan siswa dapat dilihat dari siswa aktif bertanya dan menyelesaikan soal yang diberikan guru. Kedisiplinan dapat dilihat dari siswa mengikuti proses pembelajaran sesuai dengan langkah langkah pembelajaran (Faradila, .Oleh karena itu anak akan terangsang untuk belajar baik secara individu maupun kelompok. Tujuan pembelajaran teknik inside outside circle adalah memungkinkan siswa untuk saling berbagi informasi pada saat yang bersamaan. Selain itu teknik pembelajaran inside outside circle dapat menumbuh kembangkan keaktifan anak untuk belajar yaitu dengan cara saling berbagi informasi, anak berkesempatan untuk mengolah informasi dan meningkatkan keterampilan berkomunikasi.

Azhary (2013:67) menyatakan "pembelajaran model IOC adalah suatu model pembelajaran kooperatif yang terdiri dari dua kelompok siswa yang berpasangan membentuk lingkaran". Pembelajaran dengan model Inside Outside Circle dilakukan dengan membagi kelas menjadi dua kelompok besar seperti pendapat Witteck, dkk (2004:221) mengatakan bahwa "dengan metode bola (IOC), seluruh kelompok belajar dalam fase pertama dibagi menjadi dua kelompok dengan ukuran yang sama. Kedua kelompok menyusun sebuah isu spesifik, pekerjaan di dalam kelompok dapat didukung oleh materi dan tugas yang sesuai".

Menurut Huda (2014: 246) dikatakan bahwa keunggulan model pembelajaran Inside Outside Circle adalah "adanya skruktur yang jelas dan memungkinkan siswa untuk saling berbagi informasi bersama dengan singkat dan teratur". Selain itu, model ini memungkinkan siswa untuk melatih keterampilan berkomunikasi. Siswa akan lebih paham apabila berbagi informasi dengan teman sejawatnya karena jika siswa berkomunikasi dengan siswa lain dapat menggunakan bahasa yang mereka pahami. Menurut Kurniasih \& Berlin (2016:93) "model pembelajaran Inside Outside Circle dapat memberi kesempatan pada siswa untuk bekerja dengan sesama dalam suasana gotong royong dan mempunyai banyak kesempatan untuk mengolah informasi dan meningkatkan keterampilan berkomunikasi". Dengan demikian penggunaan model pembelajaran Inside Outside Circle (IOC) dapat memungkinkan untuk meningkatkan hasil belajar IPA.

Berdasarkan uraian diatas, maka perlu dilakukan penelitian eksperimen dengan judul "Pengaruh Model Pembelajaran Inside Outside Circle (IOC) Terhadap Hasil Belajar Mata Pelajaran IPA Pada Siswa Kelas V SD Semester II di Gugus III Kecamatan Jembrana Tahun Pelajaran 2017/2018".

Bertolak dari masalah diatas, maka tujuan penelitian ini adalah untuk mengetahui perbedaan yang signifikan hasil belajar IPA antara siswa yang dibelajarkan menggunakan model pembelajaran Inside Outside Circle (IOC) dan yang dibelajarkan menggunakan pembelajaran konvensional pada siswa kelas V SD Semester II di Gugus III Kecamatan Jembrana Tahun Pelajaran 2017/2018. 


\section{Metode}

Penelitian yang akan dilakukan termasuk jenis penelitian eksperimen semu (quasi eksperiment). Populasi dalam penelitian ini adalah semua siswa SD kelas V di Gugus III Kecamatan Jembrana, Kabupaten Jembrana tahun pelajaran 2017/2018. Jumlah keseluruhan populasi adalah 149 siswa. Pengambilan sampel dalam penelitian ini menggunakan teknik class random sampling.

Sampel dalam penelitian ini adalah sebagian dari populasi yang diambil, yang dianggap mewakili seluruh populasi yaitu siswa kelas V SD N 2 Dauhwaru dengan jumlah 20 siswa dan siswa kelas V SD N 4 Dauhwaru dengan jumlah 25 siswa. Untuk mendapatkan sampel yang setara, maka terlebih dahulu dilakukan uji kesetaraan nilai Ulangan Akhir Semester (UAS) siswa kelas V semester I dengan menggunakan analisis varians satu jalur ANAVA A. Berdasarkan hasil analisis dengan ANAVA A pada taraf signifikansi 5\%, diperoleh nilai Fhit sebesar 1,21 sedangkan nilai Ftab sebesar 2,16. Dengan demikian, maka terlihat Fhit < Ftab, sehingga H1 ditolak dan H0 Diterima.

Selanjutnya, untuk pemilihan kelas eksperimen dan kontrol dilakukan dengan teknik undian. Dalam proses undian tersebut diperoleh kelas V SD Negeri 2 Dauhwaru sebagai kelas eksperimen yang diberikan perlakuan dengan menggunakan model pembelajaran Inside Outside Circle (IOC) dan siswa kelas V SD Negeri 4 Dauhwaru sebagai kelas kontrol dengan pembelajaran konvensional.

Rancangan penelitian yang digunakan adalah rancangan Non equivalent Posttest-Only Control Group Design. Desain ini dipilih karena dalam penelitian eksperimen semu tidak memungkinkan untuk merandom subjek yang ada pada setiap kelas secara utuh. .

Data yang dikumpulkan dalam penelitian ini adalah hasil belajar IPA siswa. Data hasil belajar siswa dikumpulkan dengan menggunakan metode tes. Menurut Agung (2014:92), "metode tes dalam kaitannya dengan penelitian ialah cara memperoleh data yang berbentuk suatu tugas yang dilakukan atau dikerjakan oleh seorang atau sekelompok orang yang dites (testee), dan dari tes tersebut dapat menghasilkan suatu data berupa skor (data interval)".

Varibel independent atau variabel bebas yang digunakan dalam penelitian ini adalah model pembelajaran Inside Outside Circle yang diterapkan pada kelas eksperimen. Variabel dependent atau variabel terikat yang diteliti pada penelitian ini adalah hasil belajar siswa muatan pelajaran IPA pada ranah kognitif.

Instrumen yang digunakan dalam mengumpulkan data untuk mengukur hasil belajar IPA siswa berupa tes hasil belajar IPA yaitu tes pilihan ganda. Dalam penelitian ini diambil Kompetensi Dasar 3.8 Menjelaskan siklus air dan dampaknya pada peristiwa di bumi serta kelangsungan makhluk hidup. Data yang diambil dengan instrumen ini harus benar dan dapat dipercaya. Oleh karena itu, sebelum diuji cobakan terlebih dahulu dilakuakn uji validitas isi oleh pakar atau judges selanjutnya dilakukan beberapa uji pada hasil uji coba soal sebelum soal tersebut digunakan sebagai pengambil data. Uji-uji yang dilakukan adalah: (1) uji validitas butir, (2) uji reliabilitas, (3) uji tingkat kesukaran, dan (4) uji daya beda.

Teknik analisis data yang digunakan dalam penelitian ini yaitu analisis statistik deskriptif dan uji prasyarat analisis. Pada analisis statistik deskriptif, data dianalisis dengan menghitung mean, median, modus, skor minimum, skor maksimum standar deviasi, dan varians. Dalam penelitian ini deskripsi data (mean, median, modus) tentang hasil belajar siswa disajikan ke dalam grafik poligon. Sedangkan pada uji prasyarat atau uji asumsi, data dianalisis dengan menggunakan uji normalitas distribusi/sebaran data, dan uji homogenitas varians untuk mengetahui bahwa kedua data tersebut normal dan homogen. Untuk uji hipotesis dipergunakan analisis uji t (t-test) dengan rumus (polled varians). Variabel hasil belajar IPA siswa diukur dengan memberikan post-test berjumlah 30 soal pilihan ganda dengan skor minimum ideal $=0$, dan skor maksimum ideal $=30$.

\section{Hasil dan Pembahasan}

Berdasarkan hasil analisis data yang dilakukan pada masing-masing kelompok yaitu siswa kelas $\mathrm{V}$ SD Negeri 2 Dauhwaru yang berjumlah 20 orang sebagai kelompok eksperimen dan siswa kelas V SD Negeri 4 Dauhwaru yang berjumlah 25 orang sebagai kelompok kontrol. Adapun hasil analisis data statistik deskriptif disajikan pada Tabel 2 sebagai berikut.

Tabel 2. Deskripsi Data hasil Belajar Kelompok Eksperimen dan Kelompok Kontrol

\begin{tabular}{lcc}
\hline \multicolumn{1}{r}{ Statistik Deskriptif } & Kelompok Eksperimen & Kelompok Kontrol \\
\hline $\mathrm{N}$ & 20 & 25 \\
Skor Maksimal & 28 & 26
\end{tabular}


Skor Minimal

Mean

Median

Modus

Standar Deviasi

Varians
11

19,35

19,50

20,25

4,99

24,87
10

15,32

14,45

13,70

3,85

14,81

Berdasarkan Tabel di atas, dapat dideskripsikan mean (M), median (Md), modus (Mo), varians, dan standar deviasi (s) dari data kelompok eksperimen, yaitu: mean $(\mathrm{M})=19,35$, median $(\mathrm{Md})=19,5$, modus $(\mathrm{Mo})=20,25$ varians $(\mathrm{s} 2)=24,87$, dan standar deviasi $(\mathrm{s})=4,99$.

Data hasil perhitungan post-test dapat disajikan ke dalam bentuk kurva poligon seperti pada gambar 1 berikut ini.

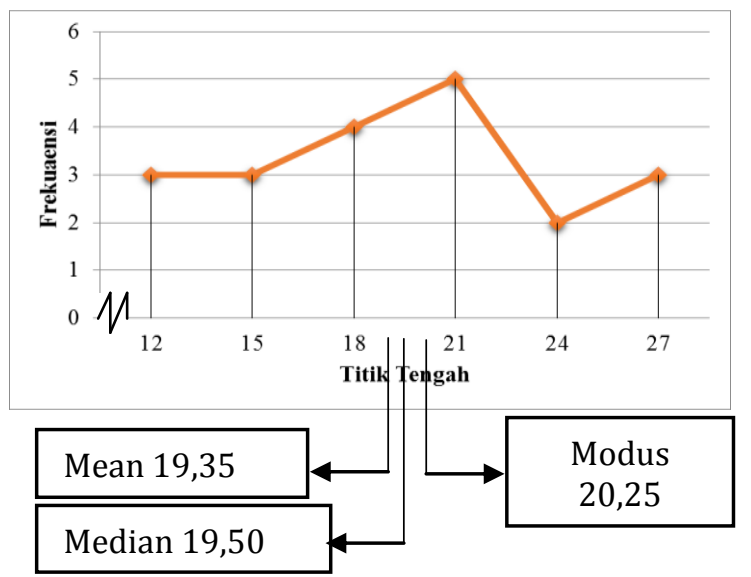

Gambar 1. Kurva Poligon Data Hasil Post-test Kelompok Eksperimen

Berdasarkan kurva poligon di atas, dapat diketahui bahwa mean lebih kecil dari median, dan median lebih kecil dari modus $(\mathrm{M}<\mathrm{Md}<\mathrm{Mo})$. Dengan demikian, kurva di atas adalah kurva juling negatif yang berarti sebagian besar skor cenderung tinggi. Untuk mengetahui tinggi rendahnya variabel hasil belajar siswa pada kelas eksperimen, skor rata-rata hasil belajar siswa dikonversikan dengan menggunakan kriteria rata-rata ideal (Xi) dan standar deviasi ideal (SDi). Berdasarkan hasil konversi, diperoleh skor rata-rata hasil belajar siswa kelompok eksperimen dengan $M=19,35$ tergolong kriteria tinggi.

Sedangkan pada kelompok kontrol dapat dideskripsikan mean (M), median (Md), modus (Mo), varians, dan standar deviasi (s) dari data hasil belajar kelompok kontrol, mean (M), median (Md), modus (Mo), varians, dan standar deviasi (s) dari data pada kelompok kontrol yaitu mean $(\mathrm{M})=15,32$, median $(\mathrm{Md})=14,45$, modus $(\mathrm{Mo})=13,70$, varians $(\mathrm{s} 2)=14,81$, dan standar deviasi $(\mathrm{s})=3,85$, data post-test kelompok kontrol dapat disajikan ke dalam bentuk kurva poligon pada gambar 2 berikut ini.

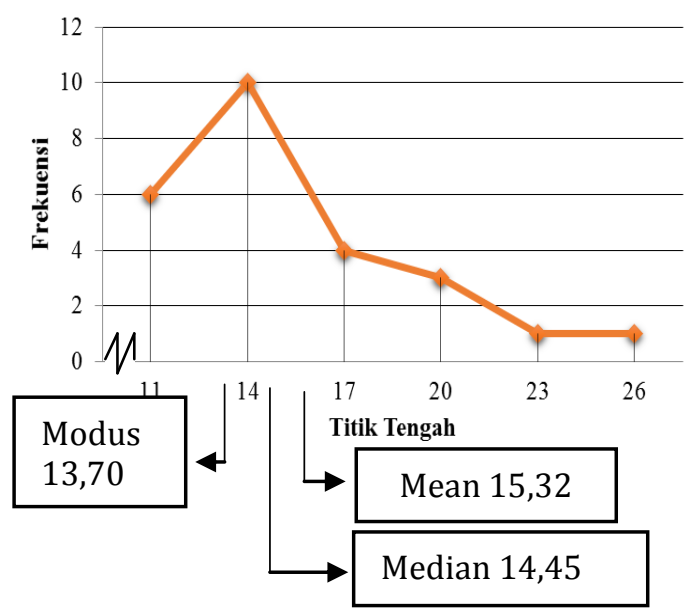

Gambar 2. Kurva Poligon Data Hasil Post-test Kelompok Kontrol 
Pada kurva poligon di atas, dapat diketahui bahwa mean lebih besar dari median dan median lebih besar dari modus ( $\mathrm{M}>\mathrm{Md}>\mathrm{Mo}$ ). Dengan demikian, kurva di atas adalah kurva juling positif yang berarti sebagian besar skor cenderung rendah. Selanjutnya, untuk mengetahui tinggi rendahnya variabel hasil belajar siswa pada kelas kontrol, skor rata-rata hasil belajar siswa dikonversikan dengan menggunakan kriteria rata-rata ideal (Xi) dan standar deviasi ideal (SDi). Berdasarkan hasil konversi, diperoleh skor rata-rata hasil belajar siswa kelompok kontrol dengan $\mathrm{M}=15,32$ termasuk kriteria sedang.

Teknik analisis data yang digunakan untuk menguji hipotesis adalah uji-t. data yang digunakan dalam uji ini adalah data hasil belajar IPA siswa. Sebelum dilakukan pengujian hipotesis dengan uji-t, terlebih dahulu dilakukan uji prasyarat (uji asumsi) terhadap sebaran data penelitian yang akan diuji hipotesisnya, yaitu uji normalitas dan uji homogenitas.

Uji normalitas sebaran data dilakukan untuk membuktikan bahwa frekuensi data hasil penelitian benar-benar berdistribusi normal. Uji normalitas sebaran data dilakukan terhadap data hasil post-test kelompok eksperimen dan kelompok kontrol. Normalitas sebaran data diuji dengan menggunakan rumus Chi-Square $\left(\chi^{2}\right.$ ) dengan kriteria pengujian, jika $\chi^{2}$ hitung $<\chi^{2}$ tabel pada taraf signifikasi $5 \%$ dan derajat kebebasan $\mathrm{dk}=($ jumlah kelas interval - parameter -1$)$, maka data berdistribusi normal. Sedangkan, jika $\chi_{\text {hitung }}^{2} \geq \chi^{2}$ tabel , maka data tidak berdistribusi normal. Rekapitulasi hasil uji normalitas sebaran data disajikan pada Tabel 3.

Tabel 3. Hasil Uji Normalitas Sebaran Data

\begin{tabular}{ccccc}
\hline No & Kelompok Data & $\chi_{\text {hit }}^{2}$ & $\begin{array}{c}\text { Nilai Kritis dengan Taraf } \\
\text { Signifikansi 5\% }\end{array}$ & Status \\
\hline 1 & $\begin{array}{c}\text { Skor Post-test pada Kelompok } \\
\text { Eksperimen }\end{array}$ & 3,063 & 7,82 & Normal \\
2 & $\begin{array}{c}\text { Skor Post-test pada Kelompok } \\
\text { Kontrol }\end{array}$ & 6,509 & 7,82 & Normal \\
\hline
\end{tabular}

Berdasarkan hasil perhitungan dengan menggunakan rumus Chi-kuadrat diperoleh harga $\chi^{2}$ hitung hasil post-test kelompok eksperimen sebesar 3,063 dan $\chi^{2}$ tabel dengan derajat kebebasan (dk) $=3$ pada taraf signifikansi 5\% adalah 7,82. Hal ini berarti, $\chi^{2}$ hitung hasil post-test kelompok eksperimen lebih kecil dari $\chi^{2}$ tabel $(3,063<7,82)$ sehingga data hasil post-test kelompok eksperimen berdistribusi normal. Sedangkan, $\chi^{2}$ hitung hasil post-test kelompok kontrol sebesar 6,509 dan $\chi^{2}$ tabel dengan derajat kebebasan $(\mathrm{dk})=3$ pada taraf signifikansi $5 \%$ adalah 7,82 . Hal ini berarti, $\chi^{2}$ hitung hasil post-test kelompok kontrol lebih kecil dari $\chi^{2}$ tabel $(6,509<7,82)$ sehingga data hasil post-test kelompok kontrol berdistribusi normal.

Setelah dilakukan uji normalitas, selanjutnya dilakukan uji homogenitas. Dalam penelitian ini uji homogenitas dilakukan terhadap varians pasangan antar kelompok eksperimen dan kontrol. Uji yang digunakan adalah uji-F dengan kriteria data homogen jika Fhitung< Ftabel. Berdasarkan hasil perhitungan post-test, diperoleh Fhitung kelompok eksperimen dan kelompok kontrol sebesar 1,68. Sedangkan Ftabel pada taraf signifikansi 5\% adalah 2,11. Hal ini berarti, varians data hasil post-test kelompok eksperimen dan kontrol adalah homogen.

Pengujian hipotesis yang dilakukan dalam penelitian ini adalah terdapat perbedaan yang signifikan hasil belajar antara kelompok siswa yang dibelajarkan dengan model pembelajaran Inside Outside Circle (IOC) dengan kelompok siswa yang dibelajarkan dengan pembelajaran konvensional. Berdasarkan uji prasyarat analisis data, diperoleh bahwa data hasil belajar kelompok eksperimen dan kontrol adalah normal dan varians kedua kelompok homogen. Setelah diperoleh hasil dari uji prasyarat analisis data, dilanjutkan dengan pengujian hipotesis penelitian (H1) dan hipotesis nol (H0). Pengujian hipotesis tersebut dilakukan dengan menggunakan uji-t dengan rumus polled varians dengan kriteria $\mathrm{HO}$ ditolak jika thitung $>$ ttabel dan $\mathrm{HO}$ di terima jika thitung < ttabel. 
Hasil perhitungan uji-t diperoleh thitung sebesar 3,06. Sedangkan, ttabel dengan ( $\mathrm{db}=43)$ pada taraf signifikansi 5\% adalah 2,021. Karena nilai thitung lebih besar dari ttabel $(3,06>2,021)$, sehingga H0 ditolak dan $\mathrm{H} 1$ diterima. Ini berarti, terdapat perbedaan hasil belajar yang signifikan antara kelompok siswa yang dibelajarkan dengan model Inside Outside Circle (IOC) dan kelompok siswa yang dibelajarkan dengan pembelajaran konvensional dalam pembelajaran IPA pada siswa kelas V SD di Gugus III Kecamatan Jembrana, Kabupaten Jembrana Tahun Pelajaran 2017/2018.

Adanya perbedaan yang signifikan menunjukkan bahwa model Inside Outside Circle (IOC) berpengaruh terhadap hasil belajar IPA siswa. Peningkatan hasil belajar siswa pada kelompok eksperimen dikarenakan pemberian perlakuan berupa penerapan model pembelajaran Inside Outside Circle (IOC) yang dapat melibatkan siswa secara aktif dalam proses pembelajaran dengan suasana yang menyenangkan. Hal ini sejalan dengan Sejalan dengan pendapat Lie (2007) menyatakan dalam model pembelajaran Inside Outside Circle siswa dapat berbagi informasi dengan sesama siswa dalam suasana yang menyenangkan sehingga memberi kesempatan pada siswa untuk mengolah informasi dan meningkatkan pemahaman siswa terhadap materi pelajaran.

Pembelajaran IPA di kelas eksperimen dengan menerapkan model Inside Outside Circle meliputi beberapa tahap pembelajaran yaitu, 1) Menyiapkan kelas untuk belajar, 2) Belajar dalam kelompok, 3) Pembagian kelompok besar dan kelompok kecil, 4) Pertukaran informasi, 5) Pergeseran posisi dan 6) Penyimpulan informasi. Pembelajaran ini menyelipkan permainan lingkaran besar lingkaran kecil yang memberi kesempatan pada siswa untuk mengomunikasikan informasi yang diperoleh kepada teman sebayanya menggunakan bahasanya sendiri. Sehingga siswa akan lebih mudah untuk memahami informasi tentang materi pelajaran yang diperoleh. Hal ini sejalan dengan pendapat yang dikemukakan oleh Redi (2013:104) mengatakan bahwa "teman sebaya mampu memberikan motivasi sekaligus suasana yang nyaman jika belajar maupun bertanya tentang materi pelajaran, hal ini dikarenakan apabila bertanya kepada guru biasanya akan memunculkan suatu ketakutan tersendiri bagi individu tersebut". Selain itu, pada tahap pertukaran informasi semua siswa mendapatkan kesempatan yang sama untuk membagikan dan menerima informasi tanpa ada siswa yang mendominasi. Permainan ini yang dapat membangkitkan semangat siswa dalam mengikuti pembelajaran yang memberikan dampak positif terhadap peningkatan pada hasil belajar IPA siswa.

Berbeda halnya dengan pembelajaran IPA di kelas kontrol dengan pembelajaran konvensional, proses pembejaran didominasi oleh guru yang lebih banyak dilakukan transfer informasi dari guru kepada siswa. Dalam hal ini guru mengambil alih sebagian besar kegiatan pembelajaran dengan menjelaskan materi pembelajaran dan siswa hanya sebagai penerima informasi dari guru. Adapun pembelajaran yang dilaksanakan pada kelas kontrol dimulai dengan penyampaian materi oleh guru, selanjutnya guru menugaskan siswa bersama kelompok untuk mengerjakan soal-soal yang terdapat di buku kemudian siswa menyampaikan jawabannya di depan kelas, diakhir pembelajaran guru menyimpulkan materi dan menugaskan siswa untuk mencatat materi yang disampaikan. Siswa tampak kurang antusias dalam mengikuti proses pembelajaran karena kurang terlibat dalam proses pembelajaran dan aktivitas siswa sebagian besar hanya sebagai pendegar dan mencatat informasi yang disampaikan oleh guru. Pembelajaran yang demikian kurang memberikan pengalaman dan tantangan bagi siswa sehingga siswa cepat merasa bosan, serta kurang motivasi dan minat untuk belajar. Pada akhirnya mengakibatkan hasil belajar IPA siswa kurang optimal.

Hasil yang diperoleh dari pengujian hipoteis menunjukkan hasil belajar IPA siswa yang mengikuti pembelajaran dengan model pembelajaran Inside Outside Circle (IOC) lebih baik daripada siswa yang mengikuti pembelajaran dengan model konvensional.

Hasil penelitian ini sejalan dengan temuan penelitian yang I Made Edi Andhika (2013) dalam jurnal yang berjudul "Pengaruh Model Pembelajaran Kooperatif Tipe Inside Outside Circle (IOC) Berbasis Media Audio Visual Terhadap Hasil Belajar IPS Siswa Kelas V SD Tahun Pelajaran 2012/2013 di Gugus II Kecamatan Tampaksiring". Hasil penelitiannya menunjukkan bahwa terdapat perbedaan yang signfikan hasil belajar IPS antara siswa yang dibelajarkan menggunakan model pembelajaran kooperatif tipe Inside Outside Circle (IOC) berbasis media audio visual dengan kelompok siswa yang dibelajarkan menggunakan model konvensional. Antari, dkk (2016:1) menyatakan hasil penelitian menunjukkan bahwa terjadi peningkatan persentase motivasi belajar dan pemahaman konsep IPA pada siswa kelas IV semester II di SD N 1 Serampingan, Kecamatan Selemadeg, Kabupaten Tabanan tahun pelajaran 2015/2016

Selain itu penelitian yang dilakukan Rahmalika (2014) menunjukkan bahwa model pembelajaran Inside Outside Circle dengan Time berbantuan multimedia dapat meningkatkan hasil belajar IPA siswa. Penelitian lainnya dilakukan oleh Retno Lestari (2013), menunjukkan bahwa penerapan model pembelajaran Inside Outside Circle berpengaruh positif terhadap keterampilan Berbicara Bahsa Inggris Kelas IV SD di Gugus X Kecamatan Buleleng. Novemie (2016) dan Rodiah (2016) menyatakan bahwa model pembelajaran IOC telah memberikan kontribusi yang signifikan terhadap hasil belajar IPA siswa. 
Berdasarkan hasil tersebut dapat disimpulkan bahwa terdapat perbedaan yang signifikan hasil belajar IPA antara kelompok siswa yang dibelajarkan dengan model pembelajaran Inside Outside Circle dan kelompok siswa yang dibelajarkan dengan pembelajaran konvensional pada siswa kelas V SD di Gugus III Kecamatan Jembrana, Kabupaten Jembrana Tahun Pelajaran 2017/2018. Sehingga dapat diinterpretasikan bahwa dengan menerapkan model pembelajaran Inside Outside Circle (IOC) dapat meningkatkan hasil belajar IPA siswa kelas V SD di Gugus III Kecamatan Jembrana, Kabupaten Jembrana Tahun Pelajaran 2017/2018.

\section{Simpulan dan Saran}

Berdasarkan hasil analisis dan pembahasan seperti yang telah diuraikan dapat disimpulkan bahwa terdapat perbedaan hasil belajar yang signifikan antara kelompok siswa yang dibelajarkan dengan model pembelajaran Inside Outside Circle dan kelompok siswa yang dibelajarkan dengan model pembelajaran konvensional dalam pembelajaran IPA pada siswa kelas V SD di Gugus III Kecamatan Jembrana, Kabupaten Jembrana Tahun Pelajaran 2017/2018. Dilihat dari perolehan rata-rata hasil post-test pada kedua kelompok yaitu hasil belajar IPA siswa kelompok eksperimen memperoleh = 19,35 sedangkan hasil belajar IPA siswa kelompok kontrol memperoleh $=15,32$. Hasil analisis tersebut menunjukkan rata-rata skor kelompok eksperimen lebih besar dari rata-rata kelompok kontrol (Meksperimen > Mkontrol). Melalui pengujian hipotesis diperoleh thitung $=3,06$. Berdasarkan taraf signifikansi $5 \%$ dan derajat kebebasan $\mathrm{db}=43$ diperoleh nilai ttabel $=2,021$. Karena thitung $=3,06$ dan ttabel $=2,021$, ini berarti thitung > ttabel maka hipotesis nol ditolak dan hipotesis alternatif diterima. Jadi dapat disimpulkan penerapan model pembelajaran Inside Outside Circle (IOC) berpengaruh terhadap hasil belajar IPA siswa kelas V SD di Gugus III Kecamatan Jembrana, Kabupaten Jembrana Tahun Pelajaran 2017/2018.

Berdasarkan hasil penelitian dan pembahasan, maka dapat diajukan beberapa saran sebagai berikut. (1) Bagi siswa, agar terlibat aktif dengan rasa senang untuk proses pembelajaran dengan menerapakan model pembelajaran Inside Outside Circle (IOC) sehingga dapat meningkatkan hasil belajar siswa. (2) Bagi guru, agar menerapkan model pembelajaran Inside Outside Circle (IOC) karena hasil penelitian membuktikan bahwa penggunaan model pembelajaran Inside Outside Circle (IOC) mampu meningkatkan hasil belajar siswa. (3) Bagi kepala sekolah diharapkan agar dapat menggunakan hasil penelitian ini sebagai bahan acuan untuk membimbing guru-guru dalam melaksanakan pembelajaran dengan menggunakan model pembelajaran yang lebih inovatif untuk meningkatkan hasil belajar siswa sehingga mutu pendidikan sekolah dapat meningkat. (4) Bagi peneliti lain agar hasil penelitian ni dapat digunakan sebagai acuan kepustakaan untuk melaksanakan penelitian dalam variabel yang sama ataupun variabel yang berbeda.

\section{Daftar Rujukan}

Agung, A. A. Gede. 2014. Metodologi Penelitian Pendidikan. Singaraja: Aditya Media Publishing.

Agung, A. A. Gede. 2016. Statistik Dasar untuk Pendidikan. Yogyakarta: CV Buana Utama.

Azhary, M.A. Yusuf Ali. (2013). "Penerapan Pembelajaran Kooperatif Model Inside Outside Circle Untuk Meningkatkan Hasil Belajar Apresiasi Dongeng Siswa Kelas VIIC MTSN Juwet Ngronggot Nganjuk". JPBSIOnline, Volume 1, Nomor 1 (hlm 66-74).

Azmi, Nurul. 2015. Model Pembelajaran Inside Outside Circle (Ioc)) Untuk Meningkatkan Hasil Belajar Siswa Dalam Proses Pembelajaran . Al Ibtida: Jurnal Pendidikan Guru Mi Volume 2 Nomor 1.

Depdiknas. 2004. Undang-Undang RI Nomor 20 tahun 2003 tentang Sistem Pendidikan Nasional. Jakarta: Depdiknas.

Edi Andhika, I Made (2013). "Pengaruh Model Pembelajaran Kooperatife Tipe Inside-Outside Circle Berbasis Media Audio Visual Animation Terhadap Hasil Belajar IPS" E-journal MIMBAR PGSD Volume 1.

Faradila, Widia Bilqis, Dwi Sulistyaningsih, Eko Andy Purnomo. 2017. Keefektifan Model Pembelajaran Inside Outside Circle Dengan Pendekatan Open Ended Terhadap Kemampuan Koneksi Matematis Kelas VIII Materi Sistem Persamaan Linier Dua Variabel . Seminar Nasional Pendidikan, Sains dan Teknologi Fakultas Matematika dan Ilmu Pengetahuan Alam Universitas Muhammadiyah Semarang.

Huda, Miftahul. 2014. Model-Model Pengajaran dan Pembelajaran. Malang: Pustaka Pelajar.

Kurniasih, Imas dan Berlin Sani. 2016. Ragam Pengembangan Model Pembelajaran. Jakarta: Kata Pena. 
Lestari, Ni Md Linda Dwi Retno. 2013. Pengaruh Model Pembelajaran Kooperatif Tipe Inside Outside Circle Terhadap Keterampilan Berbicara Bahasa Inggris Kelas IV SD Gugus X Kecamatan Buleleng. Ejournal MIMBAR PGSD Volume 1, Nomer 1 (hlm 56-72)

Lie Anita. 2007. Cooperative Learning (Mempraktikkan Cooperative Learning di Ruang-Ruang Kelas. Jakarta: PT Grasindo.

Ningsih, Sri Yunita, Susi Andriani. 2017. Penerapan Model Pembelajaran Inside Outside Circle Terhadap Kemampuan Pemahaman Konsep Siswa. MES (Journal of Mathematics Education and Science) Vol. 2, No. 2.

Novemie, Windra. 2016. "Pengaruh Model Pembelajaran IOC Dan Motivasi Berprestasi Terhadap Hasil Belajar IPA pada Siswa Kelas V”. Mimbar PGSD. Volume 4, No.1.

Rahmalika, Pt. Gd. Pande. 2014. "Pengaruh Model Pembelajaran Inside Outside Circle denganTime Berbantuan Multimedia Terhadap Hasil Belajar IPA Kelas V Gugus 2 Denpasar Timur”. E-Journal MIMBAR PGSD Universitas Pendidikan Ganesha, Volume 2 Nomor 1.

Rodiah, A. Dkk. 2016. Pengaruh Penggunaan Model Pembelajaran Inside Outside Circle (Ioc) Pada Konsep Peristiwa Alam Terhadap Hasil Belajar Siswa Kelas V Sdn Xi Cilegon. Journal Kalimaya. 4(2): 15-23.

Sudana, dkk. 2016. Pendidikan IPA SD. Singaraja: Undiksha Singaraja

Susanti, Md. Trisna, Ni Wyn Arini, Luh Pt. Putrini Mahadewi. 2017. Pengaruh Model Pembelajaran Inside Outside Circle Berbasis Lingkungan Terhadap Hasil Belajar Ipa Siswa Kelas V. e-Journal PGSD Universitas Pendidikan Ganesha Mimbar PGSD Vol. 5 No. 2.

Witteck, Torsten, dkk. 2004. "Co-operative Learning on the Internet Using the Ball Bearing Method (Inside-Outside Circle)”. Science Education International Volume 15, Nomor 2, September 2004 (hlm 209-223). 